\title{
DIFFERENCE IMPLEMENTATION OF T1WI SE AND T1WI FSPGR BRAVO SEQUENTS IN MRI BRAIN TUMOR
}

\author{
Eka Sulistyo $^{1)}$, Ildsa Maulidya Mar'athus $\mathrm{N}^{2)}$ \\ Email: ildsamaulidya2608@gmail.com
}

\begin{abstract}
Tumor is basically an uncontrolled growth of cancerous cells in any part of the body, whereas a brain tumor is an uncontrolled growth of cancerous cells in the brain. Useing of MRI in diagnose tumors can be done with various sequences. Contrast medium is needed to evince tumor enhancement, as well as sequences that support to produce tumor in post contrast, one of which uses a conventional sequence T1WI SE. This sequences often lose information in providing images in cases of brain tumors and generally more time consuming. FSPGR BRAVO is a $3 \mathrm{D}$ volumetric acquisition that captures thin section images with near isotropic or isotropic spatial resolution. This sequence displays anatomy, especially brain parenchymal anatomy, in fine detail.

The type of research in this mini research is a qualitative study with an observational approach which aims to find out sequences that can optimize post-MRI images in contrast to brain tumor cases with a short time and get the right diagnosis.

Convensional sequence of MRI TIWI SE can't detection of lessions in cerebral cortex. FSPGR BRAVO in producing images in 3D format in one-time retrieval of one particular piece and able to display anatomy especially the anatomy of the brain parenchyma in fine detail.

FSPGR BRAVO can be used to assist cause to be uprise the diagnosis of MRI brain tumor by displaying the anatomy of the brain parenchyma in more fine detail, without the need for extended time.
\end{abstract}

Keyword: MRI Brain tumor, FSPGR BRAVO, 3D volumetric.

1) RSUD Dr. Moewardi Surakarta

2) Poltekkes Kemenkes Semarang

\section{PENDAHULUAN}

Tumor pada dasarnya adalah pertumbuhan sel kanker yang tidak terkendali di bagian tubuh mana pun, sedangkan tumor otak adalah pertumbuhan sel kanker yang tidak terkendali di otak. Sebuah tumor otak bisa jinak atau ganas. Otak jinak tumor memiliki keseragaman dalam struktur dan tidak mengandung sel aktif (kanker), sedangkan tumor otak ganas memiliki ketidakseragaman (heterogen) dalam struktur dan kandungan sel aktif. Glioma dan meningioma adalah contohnya tumor tingkat rendah, diklasifikasikan sebagai tumor jinak dan glioblastoma dan astrositoma adalah kelas tumor tingkat tinggi, digolongkan sebagai tumor ganas. ${ }^{1}$
Sekitar 67.900 tumor SSP primer baru didiagnosis setiap tahun di Amerika Serikat (21 per 100.000 orang), dari 44.910 kasus tumor otak ganas. Jumlah tersebut baru didiagnosis tumor, sekitar $28 \%$ adalah glioma, yang merupakan $80 \%$ dari semua tumor otak primer ganas. ${ }^{2}$ Magnetic Resonance Image (MRI) mempunyai peran penting dalam pemeriksaan diagnostik hampir semua pasien dengan keluhan neurologis. Berbagai rangkaian MRI kompleks tersedia, untuk deteksi dan karakterisasi lesi, pencitraan fungsional, dan evaluasi respons terapeutik. Setiap sekuen MRI diciptakan dengan cermat untuk memperlihatkan jaringan atau parameter tertentu. Penting untuk 
memahami kegunaan dan keterbatasan masing-masing sekuen, sehingga serangkaian urutan yang tepat dapat dipilih dan pemindaian disesuaikan dengan kebutuhan pasien. ${ }^{3}$ Penggunaan MRI dalam menegakkan diagnosa adanya tumor dapat dilakukan dengan berbagai macam sekuen seperti DTI, spektorskopi, maupun DWI. Untuk memperlihatkan tumor secara enhancement diperlukan media kontras, serta sekuen yang mendukung untuk menampakkan tumor pada post kontras salah satunya menggunakan sekuen konvensional yakni T1WISE. Namun pada sekuen tersebut sering kehilangan informasi dalam memberikan gambaran atau pencitraan pada kasus tumor otak, sehingga diperlukan suatu sekun tambahan untuk memberikan informasi citra yang lebih lengkap. Suatu sekuen tambahan yang dapat mencitrakaan gambaran tumor dengan jelas menggunakan formart 3D adalah FSPGR BRAVO. FSPGR(Fast Spoiled GradientEcho) merupakan metode yang digunakan untuk menampilkan gambaran 3D MRI dengan meningkatkan tampilan pada sulcal structure pada beberapa kasus dikepala salah satunya pada kasus hemispheric convexities, dan mampu mengurangi asymmetric sampling pada gray matter. FSPGR BRAVO merupakan akuisisi volume $3 \mathrm{D}$ yang mampu menampilkan anatomi terutama anatomi parenkim otak dalam detail halus, hal ini memungkinkan radiolog mendapatkan dengan mudah bagian yang diinginkan setipis mungkin dengan cara memformart menjadi potongan yang dibutuhkan sesuai dengan gambaran diagnosa yang dibutuhkan. ${ }^{4}$ Sedangkan Dalam makalah ini ditujukan untuk meninjau metode konvensional MRI dengan metode baru yang digunakan untuk segmentasi MRI otak. Pengamatan dengan mengetahui perbedaan dalam penggunaan pencitaan MRI Brain kontras dengan menggunakan sekuen rutin post kontras Axial T1SE dan sekuen tambahan
T1FSPGR BRAVO pada pemeriksaan post kontras kasus tumor otak.

\section{METODE PENELITIAN}

Jenis penelitian pada mini riset ini adalah penelitian kualitatif dengan pendekatan observasional yang bertujuan untuk mengetahui sekuen yang dapat mengoptimalkan citra MRI post kontras pada kasus brain tumor dengan waktu yang singkat dan mendapatkan diagnosa yang tepat.

Satu orang pasien pemeriksaan MRI brain dengan kontras di Instalasi Radiologi Rumah Sakit Dr. Moewardi Surakarta sebagai subjek studi. 1 orang radiolog dan 1 orang radiografer sebagai responden untuk membantu peneliaian mengenai penerapan sekuen T1SE dan T1FSPGR BRAVO pada pemeriksaan MRI brain kontras. Wawancara tidak terstuktur, pencatatan hingga dokumentasi dilakukan digunakan sebagai instrument studi untuk melengkapi data yang diperlukan.

Prosedur dalam mini riset ini adalah:

1. Pasien dilakukan MRI brain kontras dengan sekun rutin yang ditetapkan di rumah sakit Dr. Moewardi Surakarta: axial T1SE

2. Sekuen opsional axial T1FSPGR BARVO diterapkan pada MRI brain kontras

3. Penilaian dilakukan secra kualitatif 1 dokter spesialis radiologi yang berpengalaman di bidang MRI 1,5 $\mathrm{T}$ untuk mencermati citra tersebut penilaian kualitatif berupa menilai kejelasan patologi yang tercitrakan pada kedua sekuen tersebut.

Data diolah dan diuji secara secara deskriptif untuk evalusai terhadap citra yang dihasilkan dalam penggunaan sekeun TISE dan T1FSPGR BRAVO pada 
pemeriksaan MRI brain kontras dalam mendeteksi tumor

\section{HASIL DAN PEMBAHASAN}

Teknik pemeriksaan MRI brain kontras di Instalasi Radiologi Rumah Sakit Dr. Moewardi Surakarta memiliki tahapan yang sama dengan teori yang sudah ada meliputi persiapan pasien, persiapan alat, pemilihan protokol, pengaturan,parameter scanning, sampai dengan proses post scanning /post, processing untuk menghasilkan gambaran yang informative untuk diinterpretasi oleh radiologist. Adapun tahapan -tahapan tersebut dijelaskan lebih terperinci sebagai berikut:

Persiapan Pasien

Persiapan yang harus dilakukan pasien sebelum melakukan pemeriksaan adalah melakukan pengecekan laboraturium pada ureum dan creatinin untuk mengetahui nilai glomerular filtrations rate (GFR) sebagai acuan fungsi ginjal pasien. Pasien / keluarga pasien melengkapi inform consent untuk persetujuan tindakan yang dilakukan. Selain itu petugas juga mengevaluasi riwayat kesehatan dan alergi pasien seperti alergi terhadap media kontras dan pasien diberi obat anti histamine jika diperlukan.

Persiapan Alat:

1. MRI $1,5 \mathrm{~T}$

2. Media Kontras Gadovist $0.5 \mathrm{mmol} / \mathrm{ml}$

3. $\mathrm{NaCl}$

4. Selimut

5. Ear plug

6. Alat fiksasi

7. Film

8. Printer

Prosedur Pemeriksaan:

Prosedur pemeriksaan setelah persiapan pasien dan persiapan alat sudah terpenuhi adalah:
1. Registrasi Identitas Pasien

Memasukkan nama, tanggal lahir, berat badan, nomor rekam medis, jenis pemeriksaan MRI, lalu memilih protokol brain navigasi lalu save maka data pasien akan secara otomatis terinput dalam sistem

2. Pengaturan Posisi Pasien

Pasien diintruksikan tidur terlentang (supine) diatas meja pemeriksaan dengan posisi head first dengan kedua tangan berada disamping tubuh. Mengatur laser setinggi glabella dan coronal lasser setinggi Meatus Acusticus Externa (MAE)

3. Pemilihan Protocol

Pada protocol brain navigasi akan secara otomatis muncul sekuen yang digunakan antara lain: Sagittal T1WI FLAIR, axial DWI, axial T2WI FLAIR, axial SPEKTROSKOPI, axial T2WI PROPELLER, axial GRE-EPI PERFUSION, axial T1WI + C SE, 3D TOF FAST ASSET

\section{Proses Scanning}

Proses scanning dilakukan setelah menentukan protocol yang digunakan, serta memastikan parameter di dalamnya sesuai dan dapat menghasilkan citra yang optimal. Setelah keseluruhan sekuen non kontras selesai, pasien diinjeksi gadovist dan $\mathrm{NaCl}$, setelah itu pengambilan gamabar menggunakan sekuen rutin axial $\mathrm{T} 1+\mathrm{C}$ SE, dilanjutkan penggunaan sekuen axial T1 FSPGR BRAVO

Parameter Scanning kontras

$\begin{array}{lll}\text { 1. } & \text { Freq. FOV } & : 22 \\ \text { 2. } & \text { Phase FOV } & : 0.75 \\ \text { 3. } & \text { Slice thickeness } & : 3 \mathrm{~mm} \\ \text { 4. } & \text { TR } & : 536 \\ \text { 5. } & \text { TE } & : 7.8 \\ \text { 6. } & \text { NEX } & : 1 \\ \text { 7. } & \text { Freq. Direction } & : \mathrm{A} / \mathrm{P}\end{array}$




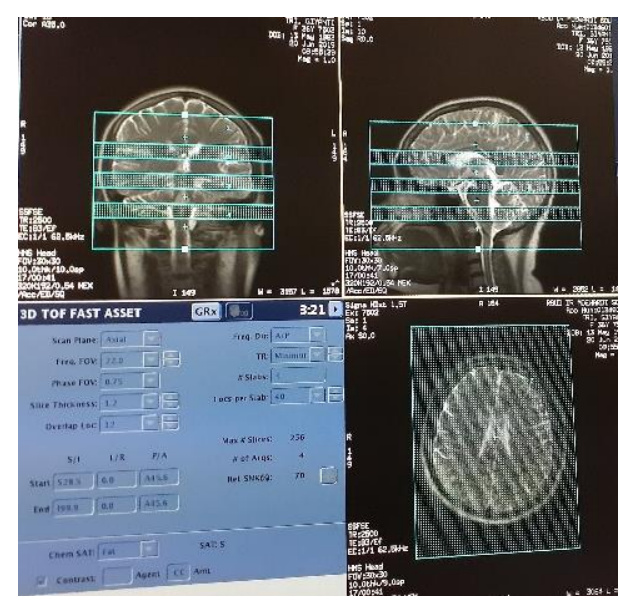

Gambar 1. Scanogram MRI brain

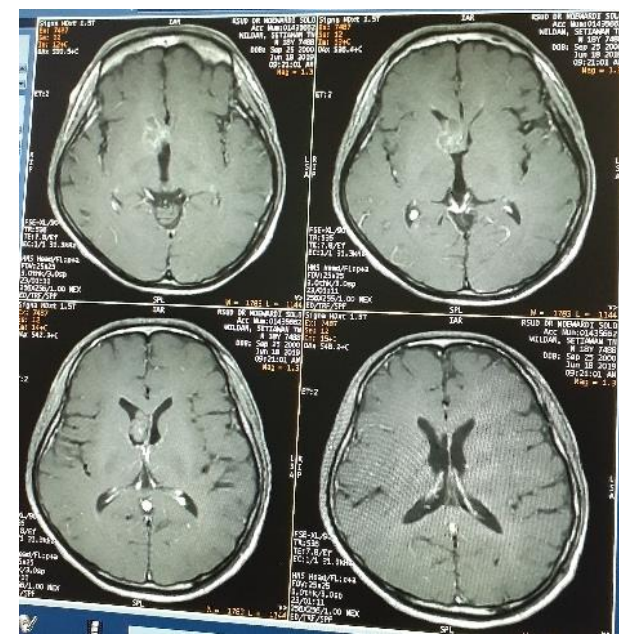

Gambar 2. Citra TIWI post kontras

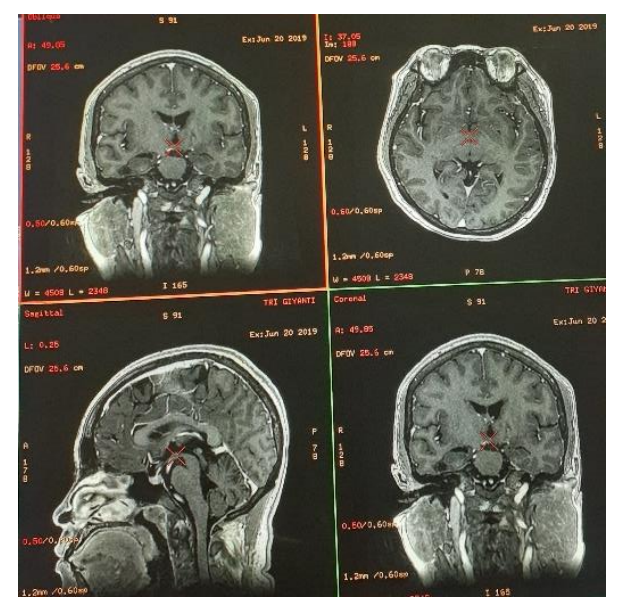

Gambar 3. Citra FSPGR BRAVO pada MRI brain kontras
Pada pemeriksaan MRI brain tumor diperlukan pemelihan protokol dengan tepat baik pada pemilihan sekun maupun paramternya. Apabila protokol tersebut tidak dipilih secara tepat maka yang akan terjadi adalah missing information terhadap penegakan diagnosa suatu penyakit. Dalam kasus ini memang beberapa metode digunakan untuk mengetahui letak tumor dikepala secara teapat, agar pemberian treatmen lanjutan tidak mengalami kendala.

MRI merupakan salah satu teknik pemriksaan penunjang dengan teknologi terkini mampu menyelesaikan beberapa masalah dalam penegakan diagnosa. Beberapa modalitas MRI dengan berbagai macam kekuatan magnet sudah beredar di pasar Indonesia diantara lain 1,5 Tesla, 3 Tesla maupun 7 Tesla. Pada mini risert ini MRI yang digunakan adalah MRI dengan kekuatan magnet 1,5 Tesla, MRI sendiri didukung dengan beberapa sekuen unggulan untuk membantu pengakan diagnosa. Kelebihan dari penggunaan MRI salah satunya dalam mendiagnosa adanya suatu masalah pada syaraf, otot maupun jaringan lunak yang ada pada tubuh, tidak menutup kemungkinan bahwa MRI dapat digunakan dalam mendeteksi tumor otak secara akurat. Untuk menampakkan adanya tumor otak, selain diperlukan sekuen yang mendukung diperlukan juga media kontras untuk penyangatan dalam penggambaran citra tumor. Untuk menghasilkan citra post kontras yang baik diperlukan sekuen yang tepat. Pada konvensional sekuen MRI post kontras dapat menggunakan T1WI SE potongan axial. Namun pada sekuen ini memiliki kekurangan yakni tidak dapat mendeteksi adanya lesi yang berukuran kecil pada cerebral cortex. ${ }^{5}$ Selain itu pada sekeun ini hanya mendapatkan satu potongan post kontras saja yakni potongan axial, apabila membutuhkan potongan yang lain seperti sagittal dan coronal diperlukan scanning tambahan, sehingga membutuhkan waktu yang cukup lama. Diperlukan suatu metode ataupun teknik 
baru dalam pengambilan gambar citra MRI agar diperoleh hasil citra pada kasus tumor otak dengan maksimal dengan waktu yang lebih efisein. Telah hadir suatu metode baru yakni FSPGR BRAVO dalam menghasilkan citra dengan formart 3D dalam penggambilan satu kali scanning pada satu potongan tertentu. Dalam makalah ini potongan diambil pada potongan axial dengan pembobotan T1WI dengan sekuen FSPGR BRAVO. FSPGR BRAVO merupakan akuisisi volume 3D yang mampu menampilkan anatomi terutama anatomi parenkim otak dalam detail halus, hal ini memungkinkan radiolog mendapatkan dengan mudah bagian yang diinginkan setipis mungkin dengan cara memformart menjadi potongan yang dibutuhkan sesuai dengan gambaran diagnosa yang dibutuhkan ${ }^{4}$. Sehingga pada pemeriksaan brain kontras dengan menggunakan sekuen tersebut dengan penggambilan satu potongan axial, dapat menambahkan potongan lain seperti sagittal maupun coronal sesuai kebutuhan diagnosa dokter dengan melihat aspek tumor dari berbagai kondisi. Selain itu dengan adanya penambahan sekuen FSPGR BRAV dapat mengurangi waktu dalam pemeriksaan MRI. Namun pada sekuen ini memiliki kelemahan yakni apabila terjadi pergerakan pada pasien maka hasil citra tidak optimal sehingga gambaran 3D dari brain tidak dapat ditampilkan dengan optimal.

\section{SIMPULAN DAN SARAN}

Metode FSPGR BRAVO dapat digunakan dalam membantu penegakan diagnosa pada MRI brain tumor dan dapat di reformart menjadi beberapa potongan sesuai kebutuhan, dengan menampilakan anotomi parenkim otak lebih detail halus, tanpa membutuhkan penambahan waktu yamg lama, sehingga pasien akan lebih nyaman dalam menjalankan pemriksaan MRI brain.

\section{DAFTAR PUSTAKA}

1. American Brain Tumor Association. http://www.abta.org.

2. Ostrom QT, Gittleman H LP. Primary brain and central nervous system tumors diagnosed in the United States. 2014.

3. Bitar R, Leung G, Perng R, Tadros S, Moody AR SJ. MR pulse sequences: What every radiologist wants to know but is afraid to ask. Radiographics. 2006.

4. Press D. Magnetic resonance imaging findings in Axenfeld - Rieger syndrome. 2013;(May 2014).

5. Alikhanov AA VRR. Magnetic resonance Imaging in the diagnosis of focal cortical dysplasia in children. 2001. 